\title{
South Africa-China Relations: A Constructivist Perspective
}

\section{Emmanuel Matambo}

Centre for Africa-China Studies

University of Johannesburg, South Africa
Article DOI:

https://doi.org/10.35293/srsa.v42i2.74

\section{Abstract}

The paper analyses South Africa-China relations emphasising how changing identities of the two countries since the 1940s define their outlook on critical issues such as human rights and democracy. Sino-South African relations are divided into three epochs. The first covers the Mao era; the second traverses the post-Mao era and the subsequent economic and modernization reforms up to the end of the Cold War; the third and current epoch roughly starts in 1994, after the establishment of democracy in South Africa. Constructivism is used as the theoretical framework to interpret the evolving South AfricaChina relationship. This study adopted a qualitative approach. The outcome of the study is that changes in identity of these two nations have shaped their national interests. Thus, when countries share identities and interests - be they good or controversial - stable cooperation is possible among them. In this vein, constructivism concedes that shared or differing identities and interests among states can produce either cooperative or conflictual relations. This distinguishes constructivism from idealism, a theory under which it has often been subsumed.

Keywords: China; Identity; Interests; South Africa; Constructivism 


\section{Introduction}

China's stupendous economic growth in the last four decades has claimed global attention. Charles Glaser (2011: 80) asserts that "the rise of China will likely be the most important international relations (IR) story of the twenty-first century". China's economic success has bolstered its influence in the international system. This development has precipitated paranoia in some regions. The West is unnerved because of an overwhelming influence of realist interpretations of international relations which conceive of a world where rising powers inevitably threaten the prevalent international political architecture, stability and power dynamics.

African governments have generally greeted China's growth with optimism due to China's self-identification as a kindred state of the global South. China has proved that, with the implementation of policies that are germane to national contexts rather than imported from foreign powers, developing countries can transcend their formidable challenges. Consequently, Africa has augmented its political and economic ties with China. However, realist interpretations of Sino-African relations predict gloom for Africa. "The China debate among international relations theorists has pitted optimistic liberals against pessimistic realists" (Glaser 2011). Literature on Africa-China relations has often drawn generalized conclusions because Africa is unwarrantedly taken as a monolithic whole.

This article employs a qualitative methodological approach to analyse China's relations with the state of South Africa. A further distinctive feature of this study is the use of the relatively underutilized constructivist approach to explain Sino-South African relations. The article proceeds to present the gist of constructivism and how it can be employed as a cogent approach for interpreting international relations as it gives actors in the international system agency rather than passivity in a supposed (realist) realm of immanent egoism and anarchy. Inevitably, the article draws comparisons between constructivism and realism, the dominant theory of international relations after the Second World War. It interrogates Sino-South African relations and how they have evolved over time, through three epochs, and conclude with recommendations for future SinoSouth African cooperation.

Constructivism has been growing gradually as a theory of international 
relations, introducing a social bent to international politics. Joseph Nye (2008) considers constructivism as an appendage to more popular theories of realism and liberalism, while Henry Nau (2012: 46-47) subsumes it under idealism.

It argues that, contrary to both realism and idealism, international relations are driven by the social structure in which actors are embedded (Adler 2013). This structure is not unchangeable. Furthermore, the structure that incorporates actors in IR gives such actors their specific social identities that consequently influence the interests that states pursue in their interaction. It argues that relations between human beings are also controlled by how they perceive themselves in relation to others, and how others perceive themselves in relations to the self (Wendt 1994: 385). Even perceptions of threats are subject to the players involved.

Nations have corporate and social identities. While corporate identities are individuating properties of nations, such as geographic size, social identities are numerous and constructed through self- and intersubjective identification. Consequently, national interests in relations among nations are subject to the identity that nations attribute to themselves and each other. Multiple identities come up because actors are involved in many institutions, pacts, regions, political affiliations, and many other factors that can impinge on an actor's self-perception. It argues that identity constructions are not exogenous to social relations (Kratochwil 2001: 17).

Constructivism does not dismiss the possibility of self-interests and the pursuit of power, but it merely states that the development of identities and interests is endogenous to social relations among actors (Checkel 1998: 324). When interacting with threats or foes, an actor may act with containment or hostility, obliterating possibilities of genuine cooperation. When an actor interacts with a friendly actor, it is possible for it to interact in ways that will benefit both parties and create authentic synergy, possibly driven by altruism. Constructivism could easily be regarded as an idealist theory because it recognizes the possibility of cooperation among states. While arguing that states can and do cooperate, constructivism is also cognizant of the fact that, subject to the social structure, actors can actually find it difficult to cooperate (Wendt 1994: 389).

This paper will, on this basis, demonstrate the changing identities of China from the time of its inception to the present day and how this shaped the perception of its national identity and interests in relations to other powers and its current state as a significant global power. 


\section{Contextualizing Sino-South African Relations}

The People's Republic of China (PRC) has been controversial since its founding in 1949. One of the divisive elements is its self-proclamation as a socialist state. In addition, its equivocal stance on human rights and democracy is at variance with the Western one. The Taiwan question has been the most crucial point of the PRC's foreign policy. After Mao and the Chinese Communist Party (CCP) toppled Chiang Kai-shek and forced his nationalist government into exile in Taiwan, the PRC has always regarded Taiwan as a renegade part of mainland China (Nau 2012). The One-China policy, by which Taiwan is not recognized as a sovereign state, has been a consistent criterion for the PRC's formal relations with other states. China has dominated its contest for recognition with Taiwan; in Africa all countries that had relations with Taiwan, save for the Kingdom of Eswatini (formerly called Swaziland), have severed these ties. These factors make China a divisive state.

Even China's participation in the African struggle against colonialism and apartheid was not independent of scepticism. Emmanuel Hevi, a Ghanaian who, for some time, was educated in China, urged African nations to be vigilant in their involvement with China. China often evoked its own history with foreign domination as the main motivation for its involvement in Africa's liberation struggle. Hevi (1967: 66) controverted this, and branded China as an imperialist actor that sought to do its own "carve up" of Africa after the end of European colonialism and imperialism.

Writing in The African Communist, Charles Akinde described China as the "enemy of African liberation" (Akinde 1977: 116). This criticism was prompted by China's behaviour during the Sino-Soviet split, when China and the postStalinist Union of Soviet Socialist Republics (USSR) were locked in ideological discord. After the Sino-Soviet split escalated into open hostility, China sought all means possible to circumscribe Soviet influence, or taint its image by calling it an imperialist and revisionist power (Kissinger 2012: 166). Africa was one of the battle grounds between the PRC and the USSR. Segal (1992) argues that prior to the conflict in the communist camp, China was not an active supporter of African liberation. Thus, China's involvement in Africa during the SinoSoviet split was not prompted by China's intrinsic concern "with the individual struggles in Africa as much as it saw the continent as undergoing a stage in the 
revolutionary process that China had endured" (Segal 1992:8) and that following the Soviet line could reroute Africa from the course to authentic socialism

China reckoned "that its revolutionary experience in a poor, peasant country was far more appropriate to African conditions than was the experience of the Soviet Union” (Segal 1992: 117). It is to China's success in proselytising its version of revolution in Africa that it received massive support from 26 African countries that voted for it as the representative of the Chinese people, paving China's way to occupy the permanent seat at United Nations Security Council in 1971 that had hitherto been occupied by Taiwan (Leslie 2016). However, in its zeal to undermine the Soviet Union, China made some costly mistakes, like backing the National Union for the Total Independence of Angola (UNITA) in Angola, a rebel outfit that was under the aegis of the West and apartheid South Africa. UNITA was fighting against the Soviet-backed People's Movement for the Liberation of Angola (MPLA) that assumed power in 1975 (Ofodile 2008). By supporting UNITA, the PRC was, unwittingly, on the same side as apartheid South Africa and the capitalist West - a curious combination for a communist country that openly vowed to fight capitalist imperialism and colonialism. Furthermore, the PRC's rapprochement with the US in the early 1970s was an expedient move, partly calculated to isolate the Soviet Union, though Richard Nixon had conceded that a country as big as China could not perpetually be left in "angry isolation" (quoted in Kissinger 2012:202).

Despite having cut ties with apartheid South Africa, China did not always enjoy the trust of South Africa's biggest liberation movement, the African National Congress (ANC) and its ally the South African Communist Party (SACP). One of the points of discord between the ANC-SACP alliance and China was the perception that the PRC continued furtive trade with apartheid South Africa, thus infringing the embargo that the ANC promoted (Akinde 1977). This allegation dented China's purported sincerity towards the struggle against apartheid. The Sino-Soviet split proved a more important factor in pitting the ANC-SACP coalition against the PRC. During the 1957 conference for socialist countries, Khrushchev exhorted "the socialist bloc to strive for 'peaceful coexistence' with the capitalist world" (Kissinger 2012: 167). Mao argued that the imperialist-capitalist nexus can only be overcome through radical revolution (i.e. violence) as enshrined in socialist lexicon (Mao 1938: 224).

The ANC has a history of non-violence and was thus bound to clash with 
China over the concept of revolution. Even after the ANC embarked on armed struggle, it did so merely to force the apartheid leadership to the negotiating table (Mandela 1994: 526). The SACP was a beneficiary of Soviet largesse; thus, it aligned itself with the USSR during the Sino-Soviet split. The South African liberation movements regarded the PRC as an aggressive state, determined to win its ideological battles "through the barrel of the gun" (Kasrils 2004: 69). The SACP also denounced China's rapprochement with the United States considering it as acquiescence in capitalism and imperialism and an affront to the Soviet Union. While the SACP considered the Soviet Union as "a rock on which the whole antiimperialist structure of the world rests” (African Communist 1979: 7), China, as mentioned above, considered the Soviet Union as a revisionist power.

By branding the Soviet Union an apostate socialist, China was obliquely presenting itself as more credible custodian of socialism. Its implacable stance antagonised beneficiaries of Soviet succour who considered it a zealot that wanted to upset the world order in its favour. This consideration fits in with realist arguments in which ambitions to change the world order are often pronounced. More recent literature of China's international relations behaviour has generally followed the time-honoured usage of realism. Shiping (2008) divides China's international relations history into two: The Maoist one and the post-Maoist one arguing that Mao's PRC could best be described as an offensive realist state, while the post-Maoist one could aptly be categorized as a defensive realist state. An offensive realist state is one that is upfront about confrontation with its foes. A defensive realist state, on the other hand, is not confrontational; it is one that cannot provoke conflict with other states under normal circumstances. Despite this division of the PRC's behaviour, Shiping (2008: 152) still concludes that that "there is little doubt that China's security strategy is still firmly rooted in realism".

Using realism to interpret China's rise implies that the PRC will disrupt the prevalent international order. John Mearsheimer (2001) argued that China's rise will be tragic for international order. Other realists assert that "China's growing strength... will lead it to pursue its interests more assertively, which will in turn lead the United States and other countries to balance against it" (Glaser 2011: 81). The 2018 trade war between China and the United States arguably bears out these bleak predictions. Mearsheimer's apprehension is explicable because if the PRC could be more assertive in its foreign policy, it could actually prove to be a more formidable competitor of the United State than the Soviet Union was. 
In fact, Peter Ferdinand (2016: 941) has observed that since Xi Jinping became president of China in 2013, China's "main emphasis is on making China 'strong and powerful' again" and that in its foreign policy China seeks to strengthen links with other powers in order "to counterbalance potentially conflictual relations with the US”' These dynamics fit into realist clairvoyance. The possible outcome of a US-China confrontation could be a repeat of the Cold War, though this time the US would be ranged against a more developed economic power. One of the most visible manifestations of China's growth is its inroads into Africa.

In general, China's interest in Africa has been a sore subject for the West, African civil society organisations, media, opposition parties and academics of a realist variety. Literature from these quarters has often, either by design or default, taken Africa as a passive and monolithic whole. Thus, even after presenting China's relations with Southern African states, Ian Taylor (2006) still concludes that these relations could all be understood through one theory - realism. In similar fashion, a dissertation on China's relations with four African countries inferred "that China's involvement in Africa can well be explained from a Realist perspective in International Relations (sic), since it is that theory that most aptly explains China's political stance towards Africa" (Botha 2006).

In 2008, Andrew Malone, a British journalist, wrote a news article in which he described the increasing Chinese population in African as an "invasion" of this "bewitching continent". His article drew parallels between the contemporary Chinese movement to Africa and the onset of European colonialism in the 19th century and concluded that China's "invasion" is happening "on a much more dramatic, determined scale” (ibid). Malone's piece is laden with bias, cynicism, and pessimism and is oblivious to the fact that a significant number of migrants of Chinese extraction who have come to Africa have done so under personal or private auspices and not any state-sponsored mission. While there are different ways that China could use to control Africa rather than the in the manner of European colonialism, Africa's veto power over who relates to the continent and how cannot be dismissed. In addition, specific countries have specific circumstances that can either allow China to relate with them in the manner suggested by Malone, or limit how China could encroach on their sovereignty.

The next section will look at constructivist framework of analysis used to interpret Sino-South African relations. 


\section{Changing Identities and Interests of the PRC from 1949: A Sino-South African Perspective}

\subsection{China under Mao: The First Epoch of South Africa-China Relations}

The People's Republic of China (PRC) was founded in 1949 after a protracted civil war that saw the nationalist government led by Chiang Kai-shek flee to Taiwan. The PRC was headed by the Chinese Communist Party (CCP) under the iconic Mao Zedong. At the nascent stages of its existence the PRC identified itself mainly as a communist state and a defender of national sovereignty. These identities informed much of the PRC's anti-imperialist stance and its justification to unify Taiwan and the PRC. A major stumbling block in the progress of the PRC was its economic weakness coupled with its ideology, which pitted the PRC against the West. The USSR was the only source of support the PRC could turn to (Schrecker 2004: 213; Price 2017).

The anti-imperialist stance that China took endeared it to Africa during anti-colonial struggles. The Bandung Conference of 1955 in Indonesia was the main platform for China to firmly involve itself in African affairs. The conference culminated in Egypt being the first African country to initiate diplomatic ties with the PRC in 1956. In its relations with South African movements, the PRC hosted members of the SACP and ANC in the 1950s and expressed its solidarity with the struggle against apartheid (Ellis 2012). Being a less developed communist power, the PRC postured itself as part of the Third World, a region that is less developed than the West and has suffered foreign domination. These identities had consequent interests which appealed to Africans.

China used its own mortifying history at the hands of the West and Japan as motivation for its involvement in Africa's travails during colonialism. The 19631964 extensive tour of Africa by Chou Enlai, the Premier of the PRC, was an important episode in Sino-African identities (Anshan 2007). Chou proclaimed that Africa was poised for revolution. This was an improvement on the PRC's commitment to African causes because it had previously advised South African anti-apartheid activists that it could not give them arms because the situation was not yet ripe for revolution. Despite Chou's undertaking, however, it is important to note that China's material aid to Africa's anti-colonial struggle was 
always outstripped by that of the USSR. The biggest undertaking in African that China made during Mao was the construction of the Tanzania-Zambia railway (TAZARA) in the 1970s (French 2014).

At the time, relations between China and South African liberation movements were volatile. This was more so during the Sino-Soviet split. Mao was an admirer of Joseph Stalin. However, the Soviet Union under Nikita Khrushchev sought to distance itself from the excesses of Stalin's rule and dogmatic socialism that promoted radical revolution as the only means of establishing socialism. The stance of the USSR was stoutly supported by the SACP and, by extension, its ally the ANC. To China, Stalin and his way of rule personified socialist tenets. It is for this reason that China described the Khrushchev-led USSR as a revisionist power anxious to "appease imperialism" (Hager 2010: 81). To the SACP and ANC, the PRC's endorsement of Stalin's style typified Mao's political taste, which meant accretion of power in the hands of a helmsman.

China had thus shifted from its previous stance of playing second fiddle to the USSR. It now postured itself as a contender for communist leadership. Its identity can thus be seen to have changed and, consequently, this revealed itself in a change of its interest. This change was to prove a crucial point in relations between the PRC and the ANC-SACP alliance. The ANC had historically committed itself to non-violence against its political opponents (Mandela 1964). Its recourse to armed struggle in the early 1960s was only made after years of nonviolence had been met with brutal force from the minority government. Nelson Mandela, the principal brain behind Umkhonto we Sizwe (Nguni expression for "Spear of the Nation"), the military component of the ANC, noted that the turn to violent struggle was aimed at compelling the Nationalist government to consider dialogue. This inclination towards non-violence was at variance with the radical Marxism that Mao's PRC swore by. China was openly against the USSR's notion that sometimes imperialism and capitalism could be conquered through parliamentary means arguing that anti-communist tendencies and edifices could only be torn down by revolutions i.e. forceful means. This was a crucial difference between China on the one hand and the USSR, SACP and ANC on the other hand.

Predictably, China sought to counter the Soviet Union. One of the reasons adduced to justify the allegation that the PRC and apartheid South African continued covert relations is that they were both against Soviet influence in 
Africa. Among South African liberation movements, China adopted the Pan Africanist Congress (PAC) which was not under the aegis of the Soviet Union. This was a disingenuous decision by the PRC because the PAC was largely ineffective, having been rendered impotent by corruption, weak leadership and fatal succession battles. In addition to this, the PAC was formed by erstwhile members of the ANC who were concerned about the influence that white communists were exercising on the largely black and nationalist ANC (Pogrund 1997). Initially, therefore, the PAC was seen as an anti-communist outfit which could receive no aid from a zealous communist state like China. From this background, it is fairly easy for anyone to surmise how the ANC-SACP alliance felt about China's expedient generosity towards the PAC.

Qin (2009) described the PRC under Mao as a revisionist state because it inveighed against the international system of that time and sought to revise it. When understood from the constructivist perspective, the apparently numerous identities of the PRC during Mao are explicable because a state can have multiple identities subject to the type of relations it shares with its political, social, historical or economic partners. It is thus understandable that China was at one point associating itself with non-aligned liberation movements in Africa but at another seeking to be the face of global socialism. These identities largely influenced the interests that the PRC had. China's initial subordination to the Soviet Union petered out during the Sino-Soviet conflict and China was openly detracting from the USSR's socialist leadership.

The PRC adhered to an outmoded brand of communist rhetoric. The USSR had moved away from literally pandering to Marxist-Leninist literature. The role of violence in political battles - as advocated by the PRC - did not easily enjoy acceptance in the ANC-SACP alliance. The SACP was bound to side with the USSR during the latter's strife with China. The ANC also followed suit.. The letup in relations between China and the ANC-SACP alliance came after the death of Mao in 1976. As will be shown, it is important that attention once again be given to the change of identity or attitude and interests of China after Mao.

\subsection{The PRC after Mao: The Modernization Epoch}

As China gained more traction in the international arena, Mao Zedong put revolutionary interests above many other interests in his international relations. 
He was more concerned, for example, with achieving untainted communism than the toppling of capitalism and imperialism (Kissinger 2012). The Cultural Revolution, which he started was a callous way of trying to cleanse China of tendencies that he thought were inimical to communism. This entailed ostracising and purging some members of the CCP, with Deng Xiaoping being one example. It was only after the death of Mao that Deng was rehabilitated in the CCP and became arguably the most influential Chinese official after Mao.

Mao's death in 1976 ushered in a transition from doctrinaire MarxismLeninism to a more progressive understanding of ideology. The reinstatement of Deng Xiaoping into the ranks of the CCP indicated China's determination to shift from Mao's modus operandi. Deng was the main architect of the modernization agenda and the market reforms that post-Mao China embarked on (Wei 2018: 531). The new agenda was tailor-made for economic and industrial development and it involved fortifying relations with other players in the international system, irrespective of their ideological leanings. Communist purity was no longer an obsession and determinant of China's international relations. Happening at the same time was the ebbing away of the Sino-Soviet conflict. Khrushchev died in 1971. Leonid Brezhnev, his heir, was conciliatory to the Chinese even before Mao's death. As early as 1973 he wrote that the Soviet Union was "consistently [coming] out for a normalization of relations and, more than that, for a restoration of Soviet-Chinese friendship" (Brezhnev 1973: 6). With Mao out of the picture, reestablishment of friendship between the two communist powers was in sight.

The internment of the "Gang of Four", comprising Mao' minions and his wife, was another signal that the PRC aimed to eclipse the vestiges of Mao's rule. Furthermore, the CCP acknowledged that the Cultural Revolution was cataclysmic and Mao the main culprit, despite maintaining that his merits outweighed his mistakes. The transition from Mao to Deng could be summarized as a shift from "revolutionary interest" to "national interest" (Hutchings 2003) that was more inclined towards economic development. In Story's (2012) words the China that "overtook the U.S as Africa's prime trade partner [did so] because China substituted the export of revolution for development at home". The identity that fits China at this stage is that of a status quo power because it benefited from the prevailing order (Hao and Ying 2009).

In the 1980s change was also discernible in South Africa. It was becoming increasingly obvious to the National Party that apartheid was unsustainable. Most 
African countries had gained independence and were governed by indigenous Africans. The apartheid government started secret negotiations with leaders of anti-apartheid movements, most notably Nelson Mandela. The South African business community also embarked on negotiations with movements that were exiled by the apartheid leadership. The wide-reaching sanctions that apartheid South Africa suffered were significantly influential in this change of attitude. The ANC, in its turn, signed the Harare Declaration which meant foreswearing "an insurrectionary approach to people's power and negotiations were paraded as the only realistic option” (Kondlo 2018: 43). Additionally, China also espoused peaceful negotiations between the antiapartheid movements and the apartheid government. Both South African liberation movements and their opponents also realized that dialogue was effective and could spare the country economic loss. Thus, at this point China, the ANC and the apartheid government converged on one thing. The ANC was more sanguine about a changed and less bellicose China. This was evident in 1983 when Oliver Tambo led a delegation to China and formalized party to party relations between the ANC and the CCP (Zhong and $\mathrm{Xu}, 2008$ ).

The second period of Sino-South African relations includes momentous periods in the recent history of global politics, the end of the Cold War being one. The Tiananmen Crisis of 1989 was China's most trying event in the second epoch (Hu 2016). The crisis started as a protest by students who were disenchanted by what they perceived as the CCP's violent intolerance to opposition and dissent. The Chinese leadership violently crushed the protests. Western condemnation that followed was interpreted as interference in China's internal affairs. The United States, up to this point, had formed close ties with China to the extent that it was not very vocal about human rights concerns in China (Mann 2000). Africa was supportive of the means China used to crush the Tiananmen protest (Samy 2010). Once again, the PRC relied on Africa for international support and presented itself as Africa's kindred spirit and a victim of Western interference and censure. To this effect, the 1990s started off on a somber note for China. The dissolution of the USSR compounded the problems of socialist states as it signaled the triumph of capitalism over socialism. The adoption of 'socialism with Chinese characteristics' is an indication that even though China professes socialism, it has abandoned ideological romanticism. In some quarters, China's economic ideology has been called state capitalism (Gu et al. 2016). 
It was almost a foregone conclusion that the ANC would win the 1994 polls in South Africa ushering a post-apartheid era. Following the "two Chinas dilemma", South Africa followed the majority of international players and abandoned ties with Taiwan in favour of the PRC. The PRC made a concession to let South Africa have any extent of relations with Taiwan short of diplomatic recognition (Shelton 2012). The option to reestablish formal relations with China has often been used by many observers to argue that post-apartheid South Africa is a pragmatic state that fits a realist paradigm.

However, when Sino-South African relations are understood from the relations that the ANC shared with the PRC during apartheid, it was almost indubitable that an ANC government would recognise China because Taiwan had formal relations with the apartheid government. Conversely, despite being geographically remote from Africa, China displayed itself as part of the Third World, sharing its colonial history with much of the Third World, and Africa in particular. In terms of propaganda, then, the identity that China claimed attracted the ANC. This intersection of identities between the ANC and the PRC produced related interests. Therefore, recognising the PRC at Taiwan's expense should be looked at from a historical perspective that has shaped current international relations between the two states. Presently, South Africa and China find themselves in the third epoch according to the divisions made in this article.

\subsection{The Establishment of South Africa-China Relations: The Third Epoch}

It was expected that post-apartheid South Africa wanted to join the international community and follow the common norm of international diplomacy. Additionally, China was increasingly becoming a global power, thanks to its modernization programme (Geldenhuys 1995). After decades of economic sanctions, South Africa wanted to improve its economy by trading with countries that held promise. The eventual return of Hong Kong to mainland China in 1997 was an extra incentive for South Africa's election to establish relations with China (Geldenhuys 1995). By 1997, Hong Kong was South Africa’s fifth trade partner. China was bound to have control over Hong Kong and hence South Africa would have faced a fraught situation had it maintained relations with Taiwan while seeking to maintain trade ties with Hong Kong. Furthermore, reunification of Hong Kong and China was going to bolster China's economy 
and extend the gap between China's economic stature that South Africa could benefit from.

China was also aware of South Africa's untold mineral resource endowments (Cheng 2009). It also coveted resources that were found in other Africa countries and "South Africa is the obvious first port of call and a partner of strategic importance" (Sidiropoulos 2007) for non-African countries that want to make forays into Africa. This mutual acknowledgement was supported by the fact that even prior to reestablishing formal relations, South Africa was one of China's biggest trade partners in Africa. Between 1991 and 1996 trade relations between the two countries improved by a massive 700 percent (Shelton 2005). The formalization of relations in 1998 was thus a validation of relations that were already staggering in their extent (Beeson, Soko and Wang 2011). The current epoch of Sino-South African relations will, like the previous epochs, display a correlation of identity and interests in the two countries as the main determinants of the formidable South Africa-China relationship.

The dissolution of the USSR, which effectively ended the Cold War and elevated the United States as the lone superpower, also created room for the emergence of regional powers (Boutros-Ghali 1992; Prys 2010). At the 2009 Heads of Missions Conference, former South African International Relations and Cooperation Maite Nkoana-Mashabane (2009) stated that the end of the Cold War "signaled the emergence of a new global power in China, new regional powers in India and Brazil in the South, and the re-emergence of Russia." It is, therefore, more effective for regional or middle powers to influence regional politics without always depending on an overstressed United States.

The BRICS, comprising Brazil, Russia, India, China and South Africa (which South Africa joined in 2009 with China's considerable encouragement) is the most renowned representative of regional or middle powers. Philani Mthembu (2018: 1) characterizes these regional leaders as "southern" rather than "emerging" powers. South Africa, being Africa's "regional hegemon” (Smith 2015: 3), is the link between the developed and democratic North and the developing South. Under Thabo Mbeki, South Africa's foreign policy concentrated more on African Renaissance (More 2002), the development of the Third World and South-South collaboration (Shelton 2005; Vale and Maseko 2002). R. W.Johnson (2009) argues that Mbeki had eyes on being the leader of the Third World. In Asia, China is the biggest economy and supports the strengthening of relations among 
countries of the South and the Third World. The aspiration to "play increasingly important roles within their own regions while simultaneously expanding their influence in various international platforms" (Mthembu 2018:1) are vital intersections in the mutual identities of China and South Africa. China supports the restructuring of institutions like the United Nations Security Council that many African states think are dismissive of African influence. As one of Africa's most suitable contenders for a Security Council permanent seat, South Africa is naturally encouraged by China's openness to reforms at the UN.

Another matter that endears China to South Africa is the former's assertion that Sino-African relations are mutually beneficial. The statement that was released at the 2006 FOCAC summit proclaimed that FOCAC supported a "strategic partnership between China and Africa featuring political equality and mutual trust, economic win-win co-operation and cultural exchanges" (China Daily 2006). To its African partners, China's approach is better than the qualified or conditional approach favoured by the West. Thus, even though China's presence and investment in African occasionally causes alarm, in general Africa "sees Chinese investment more as a development opportunity than as a security threat” (Beeson, Soko and Wang 2011).

Even though the general perception of Sino-South African trade relations is positive from South Africa's position, there has been a concern from South African trade unions over the imports that come from China. The quality of Chinese products is often dismissed as substandard and the fact that these products are readymade threatens the growth of the manufacturing industry in South Africa (Broadman 2008). This reality typifies the abhorred trade relations that Africa has with the West. Thus, in the Sino-South Africa trade equation, South Africa is "a net supplier of raw material to China" (Nadu 2007). Seen this way, China is currently not playing a meaningful role in improving Africa's manufacturing and industrial potential. However, Africa's ties with China and other rising powers should not blind the continent and tempt it into complacency and naiveté.

Despite claims that it supports a non-interference policy in national issues (Okolo 2015:32), China interferes in the domestic policies of states that go against some of its interests. This was the case when Li Baodong, China's former emissary to Zambia, threatened to cut ties with Zambia if Michael Sata, then an opposition leader who had sympathies for Taiwan, won the 2006 election (AFP, 5 September 2006). In defense, China claims that a state that recognizes Taiwan 
meddles with China's domestic affairs rather than the other way around (Adem 2010).

A strict adherence to non-interference makes Sino-South African relations means the Chinese do not help troubled parts of Africa to democratise and protect human rights. China's version of human rights is the improvement of people's economic circumstances rather than political and social liberties. In Africa, China has been deprecated by the West, media and advocacy groups as a rogue donor whose unconditional ties especially to 'rogue' Africa governments "will be damaging to Africa in the long run" (Condon 2012: 5). Its silence on political rectitude in "oppressive regimes in Myanmar, Zimbabwe or Sudan" (Story 2012) has earned China criticism from the West and non-state actors from outside China.

South Africa's own reticence on human rights violations in Zimbabwe and its continued opposition to the imposition of sanctions on that country have been interpreted as a submission to the influence of controversial members of BRICS, i.e. China and Russia (Bohler-Muller 2012). Judging from the ANC's apartheidera credentials as a campaigner for human rights and sanctions on human rights violators, it was expected in certain quarters that post-apartheid South Africa would take a firm stance on human rights allegations against the Zimbabwean government (Fairbanks 2012). The fact that this has not happened arguably suggests that South Africa's foreign policy no longer prioritises human rights. It seems to put a higher premium on stable relations with other governments even if this might infringe on the rights of non-state actors. Archbishop Emeritus Desmond Tutu "accused the [South African] government of kowtowing to China when it refused to issue a visa to his friend, the Dalai Lama, who was invited to attend the Archbishop's eightieth birthday celebrations" (Renwick 2018: xvi; see also Harvey 2012). This seeming prioritisation of stable relations over individual rights could bear out the identification of South Africa's behaviour with realism. This description, however, is reductionist.

The many international institutions in which South Africa is found confer on it different identities and interests. South Africa interacts with countries of the South and the Third World according to the history that it shares with them. The Mbeki-led government concentrated on Pan-Africanism and anti-imperialism. In action, therefore, democracy was not aggressively pontificated though it formed an essential part of South Africa's foreign policy literature and rhetoric. Nathan 
(2005: 363) argues that when Pan-Africanism, anti-imperialism and democracy are weighed against one another in South Africa's foreign policy "it is usually the democratic position that gives way" This mode of prioritisation is subject to change depending on a particular institution in which South Africa finds itself. For example, in dealing with countries of the West it is expected that South Africa will accentuate the importance of political probity in its foreign policy.

Despite its relations with the West, however, by and large South African foreign policy should be understood from the perspective of the developing world. Thus, South Africa's close relations with divisive countries like Zimbabwe, Cuba, Libya during the rule of Muammar Gadhafi becomes understandable. The ANC benefited from these countries during its campaign against apartheid. It thus feels obliged to retain them as close allies regardless of what other states might think (Schraeder 2001). The economic challenges that South Africa faces will also compel the country to cooperate with countries that can help it develop the economic welfare of a restive citizenry. At times, this priority will relegate other integral parts of South Africa's foreign policy like insistence on human rights and democracy as the sine qua non for relations.

\section{Conclusion}

The three epochs of Sino-South African relations into which the article was divided were aimed at showing how China and South Africa have shaped and been shaped by various national and international circumstances. The current China is not the China that Mao instituted in 1949. Similarly, South Africa has also undergone significant changes from 1948, when apartheid was propagated, to the current democratic era. The changes in identity have also produced changes in their national interests. The correlation of certain identities and consequent interests between China and South Africa provides room for genuine cooperation between the two countries.

A caution about Sino-South African relations is that some of the interests that the countries seek to pursue are controversial and potentially counterproductive especially for Africa. For example, South Africa's unclear stance on human rights violations in Zimbabwe could be suggestive of its departure from commitment to promote human rights. While the soft approach might be understandable at the level of state interaction, it is bound to offend ordinary citizens who endure 
the excesses of oppression governments. More alarmingly, it could suggest that South Africa is pandering to China's interpretation of human rights. Thus, when two countries share identities and interests - be they good or controversial - stable cooperation is possible among them. In this vein constructivism concedes that shared identities and interests among states can either be negative or positive. This is what sets constructivism apart from idealism, a theory under which it has often been subsumed. 


\section{References}

Adem, S (2010), "The paradox of China's policy in Africa", African and Asian Studies, Vol 9, No3, pp 334-355.

Adler, E (2013), "Constructivism in International Relations: Sources, Contributions, and Debates”, in Carlsnaes, W; Risse, T, and BA Simmons (eds), Handbook of international relations. $2^{\text {nd }}$ edition. Los Angeles: Sage, pp 112-144. AFP, (2006) "PRC Envoy Says China to Sever Ties with Zambia if Pro-Taiwan Leader Wins Polls", 5 September. (Available at: https://www.ft.com/content/ d6d5d176-3d0a-11db-8239-0000779e2340, accessed 19 December 2019).

Akinde, CO (1977) "China, The Enemy of African Liberation", The African Communist, No 70, pp 116-119.

Amusan, L (2018) "An Adventure into Twenty Years of South Africa's PostApartheid National Interest", Journal of African Foreign Affairs, Vol 5, No 3, pp 87-101.

Banchoff, T (1999), "German Identity and European Integration", European Journal of International Relations, Vol 5, No 3, pp 259-289.

Beeson, M, Soko, M and Y, Wang, (2011) "The new resource politics: can Australia and South Africa accommodate China?", International Affairs, Vol 87, No 6, pp 1365-1384.

Bohler-Muller, N (2012), "Nuanced Balancing Act: South Africa's National and International Interests and its 'African Agenda", South African Foreign Policy and African Drivers Programme Occasional Paper No 120. Johannesburg: SIIA.

Botha, I (2006), "China in Africa: Friend or Foe? China's Contemporary Political and Economic Relations with Africa”, Master's Dissertation, Stellenbosch University.

Boutros-Ghali, B (1992), Agenda for Peace. New York: UN.

Brezhnev, L (1973), "The USSR"s Foreign Policy: Peace is indivisible", Vital Speeches of the Day, Vol 40, No 1, pp. 4-6.

Broadman, HG (2008), "Chinese-African Trade and Investment: The Vanguard of South-South Commerce in the Twenty-first Century", China into Africa: Trade, Aid, and Influence, pp 87-108.

Butts, HK and RP Thomas (1986), The Geopolitics of Southern Africa: South Africa as Regional Superpower. Westview: Westview Press. 
Carr, EH (1956), The Twenty Years'Crisis.1919-1939: An Introduction to the Study of International Relations. London: The Macmillan Press.

Checkel, JT (1998), "The Constructivist Turn in International Relations Theory" World Politics, Vol 50 No 2, pp 324-348.

Cheng, JYS, and S Huangao (2009), "China's African Policy in the Post-Cold War era,,Journal of Contemporary Asia, Vol 39, No 1, pp 87-115.

China Daily (2006), "Declaration Calls for Enhanced Ties." (Available at: http:// www.china daily.com.cn/ china/2006-11/06/content_725766.htm, accessed 19 December 2019)

Declaration of the Beijing Summit of the Forum on China-Africa Co-operation. Available at: http: //www.focac.org/eng/zxxx/t 280370.htm, accessed 19 December 2019)

Condon, M (2012), "China in Africa: What the Policy of Nonintervention adds to the Western Development Dilemma", PRAXIS The Fletcher Journal of Human Security, Vol 27, pp 5-25.

Ellis, S (2012), External Mission: The ANC in Exile, 1960-1990. Johannesburg: Jonathan Ball.

Fairbanks, E (2012), "South Africa's Awkward Teenage Years: The Rainbow Nation has finally arrived on the world stage - but did its conscience stay at home?", Foreign Policy, No 191, pp 38-40.

Ferdinand, P (2016), "Westward ho-the China Dream and 'One Belt, One Road': Chinese foreign policy under Xi Jinping”, International Affairs, Vol 92, No 4, pp 941-957.

Geldenhuys, D (1995), South Africa and the China question: A Case for Dual Recognition. Vol. 6. East Asia Project (EAP), Dept. of International Relations, University of the Witwatersrand.

Glaser, C (2011), "Will China's Rise Lead to War? Why Realism Does Not Mean Pessimism”, Foreign Affairs, No 80, pp 80-91.

Gu, J; Zhang, C; Vaz, A and L Mukwereza (2016), "Chinese State Capitalism? Rethinking the Role of the State and Business in Chinese Development Cooperation in Africa", World Development, No 81, pp 24-34.

Hager, RP (2010), "A Failed Empire: The Soviet Union in the Cold War from Stalin to Gorbachev", Democracy and Security, No 6, pp 81-83.

Hao, Y and H Ying (2009), "Chinese Foreign Policy Making: A Comparative Perspective”, Public Administration Review, No 69, pp 136-141. 
Harvey, E (2012), Kgalema Motlanthe: A Political Biography. Johannesburg: Jacana. Hevi, E (1967), The Chinese Communists and Africa. New York: Praeger.

$\mathrm{Hu}, \mathrm{X}$ (2016), "Legacy of Tiananmen Square Incident in Sino-US Relations (post2000)", East Asia, Vol 33, No 3, pp 213-232.

Hutchings, G (2003), Modern China: A guide to a Century of Change. Cambridge: Harvard University Press.

Johnson, RW (2009), South Africa's Brave New World: The Beloved Country since the End of Apartheid. London: Penguin Group.

Johnston, AI (2008), Social States: China in International Institutions, 1980-2000.

Princeton: Princeton University Press.

Kasrils, R (2004), Armed and Dangerous: From Undercover Struggle to Freedom. Johannesburg: Jonathan Ball.

Kissinger, H (2012), On China. London: Penguin.

Kondlo, K (2017), "From the Fringes to Fossils: The Pan Africanist Congress of Azania and the Negotiated Transition to Democracy in South Africa, 19901994”, Journal for Contemporary History, Vol 42, No 1, pp 39-58.

Kratochwil, F. V (2001), "Constructivism as an Approach to Interdisciplinary Study”, in Fierke, KM and KE Jøgensen (eds) Constructing International Relations: The Next Generation. New York: M.E Sharpe.

Mandela, N (1994), Long Walk to Freedom. Randburg: MacDonald Purnell.

Mandela, N (1964), "Statement from the Dock at the Opening of the Defence Case in the Rivonia Trial” (Available at: http://www.anc.org.za/show.php?id=3430, accessed 5 April 2012).

Mann, J (2000), About Face: A History of America's Curious Relationship with China. New York: Vintage.

Mao, Z (1938), Problems of War and Strategy. Selected Works, Vol 2. Oxford: Pergamon Press

Mao, Z (1961), Selected Works of Mao Tse-Tung, Vol 4. Oxford: Pergamon Press Mearsheimer, J (2001), The Tragedy of Great Power Politics. New York: Norton. Men, J (2011), :Between Human Rights and Sovereignty-An Examination of EU-China Political Relations”, European Law Journal, Vol 17, No 4, pp 534-550. More, M. P (2002), “African Renaissance: the Politics of Return”, African Journal of Political Science, Vol 7, No 2, pp 61-80.

Morgenthau, H and, KW Thompson (1985), Politics among Nations: The Struggle for Power and Peace. $6^{\text {th }}$ edition. New York: Alfred A. Knopf. 
Mthembu, P (2018). China and India's Development Cooperation in Africa: The Rise of Southern Powers. London: Palgrave Macmillan.

Naidu, S (2007), "China-African Relations in the 21st Century: A 'Win-Win" Relationship”, in International Relations and Security Network. Uppsala: Nordic Africa Institute, pp 41-46.

Nathan, L (2005), "Consistency and Inconsistencies in South African Foreign Policy”, International Affairs, Vol 81, No2, pp 361-372.

Nau, HR (2012), Perspectives on International Relations: Power, Institutions, Ideas. Washington, DC: CQ Press.

Nicholson, M (2002), International Relations: A Concise Introduction. $2^{\text {nd }}$ edition. Hampshire: Palgrave Macmillan.

Nye, J (2008,) "International Relations: The Relevance of Theory to Practice”, in Reus-Smit, C and D Snidal, Oxford Handbook if International Relations. Oxford: Oxford University Press.

Ofodile, UE (2008), “Trade, Empires, and Subjects—China-Africa Trade: A New Fair Trade Arrangement, or the Third Scramble for Africa?”, Vanderbilt Journal of Transnational Law, Vol 41, pp 505-583.

Okolo, AL (2015), “China’s Foreign Policy Shift in Africa: From Non-Interference to Preponderance”, International Journal of African Renaissance Studies, Vol 10, No 2, pp 32-47.

Pogrund, B (1997), How can Man die Better? The Life of Robert Sobukwe. Johannesburg: Jonathan Ball.

Price, RF (2017), "Convergence or copying: China and the Soviet Union", in Hayhoe, $\mathrm{R}$ and M Bastid (eds.). China's Education and the Industrialised World. London Routledge.

Prys, M (2010), “The Variability of Regional Powers”, Paper presented at the SGIR 7th Pan-European Conference on IR, Stockholm, pp 9-11.

Qin, Y (2009), "Rationality and Processual Construction: Bringing Chinese Ideas into International Relations Theory”, Social Sciences in China, Vol 63, pp 5-20.

Renwick, R (2018), How to Steal a Country: State Capture and Hopes for the Future in South Africa. Johannesburg: Jacana.

Samy, Y (2010), "China's Aid Policies in Africa: Opportunities and Challenges", The Round Table, Vol 99, No 406, pp 75-90.

Schraeder, PJ (2001), "South Africa's Foreign Policy: From International Pariah to Leader of the African Renaissance", The Round Table, Vol 90, No 359, pp 
229-243.

Schrecker, JE (2004), The Chinese Revolution in Historical Perspective. Westport: Praeger.

Segal, G (1992), "China and Africa”, Annals of the American Academy of Political and Social Science, Vol 519, No 1, pp 115-126.

Seymour, V (1996), "Global Dialogue, Human Rights and Foreign Policy: Will South Africa Please Lead", Southern African Perspectives, No. 55. Cape Town: Centre for Southern Africa Studies.

Shelton, G (2005), "China, Africa and South Africa Advancing South-South Cooperation", in Politics and Social Movements in an Hegemonic World: Lessons from Africa, Asia and Latin America. Buenos Aires: CLACSO.

Shelton, G (2012), "Hong Kong — South Africa's Gateway to China”, in African perspectives. Global insights. SIIA, pp 1-24.

Shiping, T (2008), "From Offensive to Defensive Realism: A Social Evolutionary Interpretation of China's Security Strategy", China's Ascent: Power, Security, and the future of International Politics. Ithaca, NY: Cornell University Press.

Sidiropoulos, E (2007), "African Regional Powers: The Foreign Policy of South Africa”, Instituto Portugues de Relacoes Internacionais, No 33, pp 1-18.

Smith, K (2015), "R2P and the Protection of Civilians: South Africa's Perspective on Conflict Resolution”, Global Powers and Africa Programme Policy Briefing, No 133 , SIIA.

Story, J (2012), “China' Africa Policy: A Matter of Development. China”, in Africa Policy: INSEAD Knowledge. (Available at: knowledge.insead.edu/economicspolitics/chinas-africa-policy-2282, accessed 2 October 2019).

Switzer, T (2015), “Lee's Advice to Nixon, 1967: End China's Isolation”, The American Interest, 31 March.

Taylor, I (2006), China and Africa: Engagement and Compromise. Routledge: Abingdon.

Vale, P and S Maseko (2002), "Thabo Mbeki, South Africa, and the Idea of an African Renaissance", in Jacobs, S and R Calland (eds) Thabo Mbeki's World. London: Zed, pp. 13-29.

Wei. X (2018), “Lenin's NEP and Deng Xiaoping's Economic Reform”, In The Palgrave Handbook of Leninist Political Philosophy. London: Palgrave Macmillan. Wendt, A (1994),“Collective Identity Formation and the International State”, The American Political Science Review, Vol 88, No 2, pp 384-396. 
Wendt, A (1995), “Constructing International Politics", International Security, Vol 20, No 1, pp 71-81.

Williams, C and C Hurst (2018), "Caught Between Two Chinas: Assessing South Africa's Switch from Taipei to Beijing”, South African Historical Journal, Vol 70, No 3, pp 559-602.

Zhong, W and S Xu (2008), "China's Support for solidarity with South Africa's Liberation Struggle", The Road to Democracy, Vol 3, No 2, pp 1213-1252. 